Oluwafemi, A. J., Adebiyi, S. O. (2018). Customer Loyalty and Integrated Marketing Communications among Subscribers of Telecommunication Firms in Lagos Metropolis, Nigeria. Journal of Competitiveness, 10(3), 101-118. https://doi.org/10.7441/joc.2018.03.07

\title{
CUSTOMER LOYALTY AND INTEGRATED MARKETING COMMUNICATIONS AMONG SUBSCRIBERS OF TELECOMMUNICATION FIRMS IN LAGOS METROPOLIS, NIGERIA
}

\section{- Olaolu Joseph Olunvafemi, Sulaimon Olanrewaju Adebiyi}

\begin{abstract}
Strategies for improving customer loyalty are a sine qua non for attracting new customers and retaining old ones in order to improve firms' sustainable competitiveness. However, choice of marketing communication mix would differ between firms and across industries. This study examines the influence of integrated marketing communications (IMC) dimensions on customer loyalty to mobile telecommunication service among competing firms in telecommunication service industry. Using cross-sectional survey research design, multistage sampling procedure (stratified, quota and simple random) sampling techniques, data was collected from 150 respondents out of which $n=134$ copies of the retrieved questionnaires. The data was analysed using descriptive and inferential statistics (correlation and regression), while hypotheses were tested using the analysis of variance (ANOVA). The results show a significant relationship between customer loyalty and direct marketing $\left(\mathrm{r}=.375^{* *}\right)$; publicity $\left(\mathrm{r}=.514^{* *}\right)$; sales promotion $\left(\mathrm{r}=.470^{* *}\right)$ and advertising $\left.\mathrm{r}=.562^{* *}\right)$ respectively. The multiple regression result indicates $\mathrm{R}^{2}$ value of .483 , meaning that integrated marketing communication dimensions accounted for $48.3 \%$ variance in customer loyalty. The study therefore recommends IMC as a strategic tool for targeting subscribers to patronize and retain them with a mobile telecom service provider for a long time. It further suggests that managers in the industry should prioritize their strategies on the basis of IMC dimension that makes the greatest contribution to the criterion of interest, with beta and high coefficient in their budgetary allocation for the optimal promotional mix to achieve the organisational goal both in short and long-run.
\end{abstract}

Keywords: customer loyalty, direct marketing, publicity, sales promotion, advertising, consumer buying decision, telecom competitiveness

JEL Classification: C830, D12, M1, M31, M37, M210

Received: October, 2017

1st Revision: May, 2018

Accepted: July, 2018 


\section{INTRODUCTION}

The ability of a firm to build and maintain successful long-term relationships with a sizeable chunk of its share of market is one of the most crucial tasks confronting firms in today's competitive business environment (Hegner-Kakar et al., 2018). For any profit-oriented firm losing customers is deemed to be very costly, as a loyal customer purchases more, often demonstrates a higher willingness to spend on the firms' offerings, and often acts as an advocate for the company to other consumers (Harris \& Goode, 2004). The researchers' observation suggests a low incidence of customer loyalty in the telecommunication Nigeria industry owing to high rate customer churn (Oyatoye et al., 2015). The above arguments are of special relevance in the telecommunication sector as it faces the challenge of a partial customer defection more than in any other industries industry due to the introduction of multiple SIM cards on customers' phones. Although argument has been made that only a minority of customers actually permanently leaves their telecommunication service provider, many customers simultaneously enter relationships with other providers in search of better deals and have the luxury and freedom to exit any time (Oyatoye et al., 2017).

However, customers spread their portfolio of services and offerings from service providers, thereby reducing the individual firm's market share (Aurier \& N'Goala, 2010). Given the acceptance of the link between loyalty and financial outcomes (Anderson \& Mansi 2009; Fornell et al., 2009; Lariviere, 2008; Anderson \& Mittal 2000; Edvardsson et al., 2000; Hallowell, 1996), and the fact that it costs less to retain a customer than attracting new ones, achieving long-term relationships and the development of customer loyalty have become a central issue in marketing (Li et al., 2013; Athanasopoulou, 2009). In addition, the need to examine the implications of budgetary allocation of mobile telecommunication service providers to their integrated marketing communication initiatives and operating efficiency cannot be overemphasized.

In Nigeria today, there exists a high prevalence of multiple SIM cards vis-a-vis phone users among subscribers in its maturing telecom market. In addition to the fact that the cost of buying SIM diminishes daily and almost zero naira for network service providers, there is the need for researchers and industry practitioners to assess the usefulness and the contribution of each of the dimensions of IMC systems to customer loyalty of a particular service provider.

The telecommunication industry market in Nigeria is approaching maturity in which the total of subscribers is approaching the total of consumer base population of the country. It is imperative for managers to ensure a good relationship with the firm`s customers. It has been observed that the cost of attracting customers is about five times higher than the cost of retaining existing subscribers. Quite often the bulk of new subscribers patronizing a given firm may be customers that churn from competitor firms. There exists a greater possibility that part of the customers on the firm's network may also churn to one or more of the competitor firms providing similar telecommunication services. There is therefore the likelihood that this situation will result in depletion of a firm's market share in addition to other negative consequences on the firm's position in the market. Wang \& Wu (2012) state that recruiting new customers cannot guarantee long-term success for an organisation especially when that firm cannot retain its customers, therefore it is not economically and socially reasonable for a firm to deploy organisational resources to attracting new customers in the short-run without retaining such customers in the long-run (Oyatoye et al., 2017). 
Service providers currently facing the onerous challenge in implementing customer-oriented marketing strategies aimed at creating customer value (Hubber et al., 2001) as well as enhance customer loyalty by initiating integrated marketing communication (IMC) strategies. Therefore, the aim of this study is to examine the relationship between integrated marketing communications system and customer loyalty. It is instructive to note that firms need to move beyond the conventional approach to running promotional services similar to those of other competitor firms as it has currently been practiced in the Nigeria market (Oyatoye et al, 2017; Olimpia \& Mihalea, 2015). An understanding of the influence of each dimension of the integrated marketing communication (IMC) system on customer loyalty will not only help improve a firm's performance and competitiveness, it would also make a useful contribution to knowledge in marketing management literature (Chaihanchanchai \& Anantachart, 2017).

It is worthwhile to note that subscribers especially in the mega cities like Lagos are more sophisticated in making their choice among varieties of competitive telecoms products and service offerings with similar incentive packages and the extent to which these offerings satisfy their telecommunication needs. Thus, service providers need to move beyond the old-fashioned approach to isolating specific promotional element to ensure an optimal mix of IMC tools in promoting their products and services. Such an approach would assist the firm in attracting and retaining loyal subscribers by prioritizing and meeting the needs at the mind of subscribers.

The Nigeria telecommunication market is deregulated and liberalized, thus this industry subsector is highly competitive. Therefore, customers should be offered sophisticated products and services in order to keep the firm the heart of subscribers. Products and services should not only be provided to consumers, rather information about such product and service offerings should be effectively communicated to the consumers. To this end, marketing tools such as IMC provides a platform for telecommunications service providers to be able to make the customer gain profound understanding of firm's ability to provide products or services that meet the telecommunication needs of subscribers, thereby stimulating and sustaining subscribers' patronage that would result in customer loyalty. It is not sufficient for service operators in any competitive market to provide quality service, but it is worthwhile that firms' needs to communicate within a reasonable budget everything that subscribers may need to know about current and future brand, in order to take informed decisions favourable to the firm.

Moreover, contemporary means of ensuring an effective two-way communication between the firm and customer is IMC, as it gives firms the opportunity to integrate various marketing activities aimed at ensuring that customers are not only well-informed about telecommunication services available at present and those that will be available in the future, but also to remind and persuade subscribers to patronize a firm's products and services and not those of the competitors.

In view of the above, the need to strengthen customer loyalty strategies of any firm cannot be overemphasized since it has been observed that it costs less to retain than attracting new customers, which makes the study of this nature stimulating and worthwhile for telecommunication industry that spends a lot on promotional activities.

Besides, the business organisation cannot operate without communicating with stakeholders as it gives the firm a unique opportunity of creating relationships with other stakeholders, provid- 
ing information on both what the firm does and does not do (Duncan \& Moriarty, 1998). Thus, this study aimed at assessing the influence of integrated marketing communications dimensions on customer loyalty to network service providers in Nigeria. The outcome of this study would offer telecommunication firms opportunity to understand subscribers' preferences among the IMC activities. An understanding of the IMC elements that influences subscribers purchase decision most would help stimulate good relationship between subscribers and the firm as a result of the ability of the firm to capitalize on the preferred IMC activities in formulating strategies to ensure enduring relationship with the firm.

Furthermore, customer perception of service delivery and standard differs as well as their loyalty to service providers, since the expectation of an average subscriber in an $\mathrm{x}$ amount of stake or investment in a service firm differs from one another. The need for research on customer loyalty cannot be overemphasized since it has been argued that the cost of attracting a new customer to patronise the firm's products/services is said to be five times more than the cost of retaining an existing customer (Barsky, 1994). The need to keep the customer loyal to a firm born out its derivatives ranging from short to long-term for the stakeholders.

Although, marketing communications effort emanates from the firm with a view to reach out to customers who serve both the economic and social justification for the establishment of business organisation (Drucker, 1973). For the communication efforts and resources of the organisation to be effective, it must be customer-focused, by meeting customer expectations from the firm, its products/services regarding the interaction that takes place or will take place in their relationship (Hänninen \& Karjaluoto, 2017).

Therefore, this study set out to empirically disentangle from customers' position the influences of IMC dimension on customer loyalty to telecommunication firms ' with view to estimate the customer perspective of the effectiveness of firms promotional and marketing communications efforts. This is necessary since IMC enjoys the benefits of different marketing communications activities in order for any firm that employs this promotional strategy to optimize the positive outcomes of the firm's communications with customers and enjoys the customers' patronage and repeated purchase of the firm's products and services for competiveness

\section{THEORETICAL BACKGROUND}

The theoretical framework underlying this study is the stimulus-organism-response (S-O-R) theory (Mehrabian \& Russell, 1974). The IMC program is conceived as the stimulus, while the customer is the organism and customer loyalty is the response. The S-O-R theory indicates that organism can mediate the effect of stimulus on response (Wu \& Li, 2016). The core proposition therefore is that the formation of CL begins with effective and efficient IMC strategies, followed accurate delivery to consumer (organism) and finally this will result in the output (customer loyalty) response.

Integrated marketing communication (IMC) in the recent times centred on customers who are the essence of any business, as most definitions tend towards integrating different marketing communications disciplines to inform, persuade and remind customers to patronize the company, its products and services. According to Kotler (2003), IMC has a way of looking at the whole 
marketing process from the viewpoint of the customer, which is ensuring a marketing communications discipline that stimulates mutual benefits for both the company and its customers. Moreover, Kotler et al. (1999) defines IMC as 'the concept under which a company carefully integrates and coordinates its communications channels to deliver a clear, consistent and compelling message about the organization and its products.' IMC is an approach where firms communicate a firm's brands through the integration of different elements of a promotional mix for working together to create a seamless experience for the customer and are presented with a similar tone and style that reinforces the brand's core message. The fundamental goal of IMC is to maximize the synergetic potentials of different marketing communications discipline as a whole and not in isolation, which in most cases maximizes their cost-effectiveness (Csikósová et al., 2014).

The following are five principles underlying IMC; customer prospecting through identification of customer's needs, effective and efficient use of relevant contacts or touch points to reach target consumers, communicating with a single voice meaning that all messages relayed to targets across communication channels and touch points should be consistent, consolidating relationships with customers, and lastly, it must generate appropriate behavioral response (Shimp \& Andrews, 2013).

Furthermore Schultz (1993) operationalised these in six steps namely; outside-in planning, which emphasizes consumer needs, then the use the collected data to select the most suitable communication approach to meet the consumer's needs, developing a customer-oriented database, which helps marketers understand and predict consumer behaviors, as well as aid them in reaching the right targets, brand contacts which entail integration of different marketing communications disciplines in order to produce a greater impact than using a single tool. Initiate zero-based planning by making current market environment and brand situation to plan and budget, communication with one voice in order to harmonize of communication tool to the same brand concept, adopting a cross-functional work in order to focus activities towards a common goal (Kliatchko, \& Schultz, 2014), drawing on the resource-based view theory, Luxton et al. (2015) that investigates how an integrated marketing communication (IMC) capability drives a brand's financial performance through influencing the effectiveness of communication campaigns and the brand's market-based performance. The results illustrate that an IMC capability has a significant direct effect on campaign effectiveness and significant indirect effect on a brand's market-based performance and financial performance. The study highlights the role of IMC as a key firm-specific capability with a significant impact on performance outcomes. The study concludes that firms need to be competitive in building distinctive IMC capability, which in turn leads to superior brand market-based and financial performance.

On the other hand, customer loyalty can be viewed as an important concept in business used to strengthen the purpose of existence of any business. According to Anderson and Jacobsen, (2000), customer loyalty is the result of organization's creating benefits for customers so that they will maintain and increasingly repeat business with the organisation. The benefits can be created through effective implementation of an assortment of IMC dimension for mutual benefit of the customer and the firm. In addition, Van Vuuren et al. (2012) specify that customers are loyal to a firm whenever they have been satisfied consistently, and they tend to become passionate about doing business with, and loyal to the firm. A recent cross-sectional survey of book 
stores customers was taken in Romania between June and August 2015 by Tichindelean (2015). The data collected were analysed using descriptive statistics, Pearson correlation and the analysis of variance (ANOVA). The results reveal that online advertising activities and managing events have the highest influence on the clients' buying behaviour. The present study will examine the holistic effect of IMC dimensions on subscribers' loyalty in the offerings of one fastest growing telecommunication sector of Africa's most populous nation.

In another study, Thaichon \& Quach (2015) investigate the relationship between two elements of marketing communications - advertising and sales promotion, in relation to customer loyalty towards service providers in Thailand. Using secondary data to assess the variables found that customers' value and trust leads to attitudinal and behavioural loyalty. This study is limited in application as it does not explore all the relevant dimensions of IMC. It did not equally collect the data directly customers that IMC efforts and resources are aiming at in order to assess how effective is the integration from demand side (customers that the company is communicating their product and service attribute to). This current study tries to fill this gap by collecting data on the four dimensions of IMC mostly used in Nigeria from the subscribers of telecommunication firms.

In the work of Khizar et al. (2016), who assessed the effects of IMC components on brand awareness and customer loyalty using primary data collected through questionnaire administered to 105 managers working in the selected Pakistan Beverage sector listed at Lahore Stock exchange. The data was analysed through the descriptive statistical technique by using the graph and Pearson Bivariate Correlation Matrix and regression analysis. The result revealed that IMC positively affect brand awareness and customer loyalty. This study assessed the effect of IMC from the supplier side of the service provider rather than the demand side where a customer who is a direct target of IMC request for the product or service.

In the same way, Cogoljević et al. (2017) pointed out the basic advantages of a strategic approach and functioning of the integrated marketing communications (IMC) concept in companies in the Republic of Serbia. With a sample of databases using the survey method, estimated results based on 42 samples indicate that the strategic approach to IMC concept lead to a positive impact on companies' businesses. However, a large number of companies in the country (Serbia) continues to rely more on traditional forms of marketing communication. Thus, there is the need for empirical research on why or not some firms may abandon implementation of IMC in a world where customers are the only economic and social justification for business existence. Moreover, IMC have strategic implications on firms` ability to compete favorably in the market, particularly in the telecommunication industry where service providers offer similar services to homogeneous customers in the same market.

Likewise et al. (2017) explore the incorporation of social media (SM) within the organisations' marketing communications. The authors drew on grounded theory methodology to conduct an in-depth interview with senior marketers for the first phase of data collection which guides the other two- phases of data collection within the fast moving consumer goods (FMCG) sector of the Australian economy. The study found out that integrating implementation solution will allow IMC to leverage on social media unique strengths into marketing capabilities. However, none of the existing three sequential decision-making models as developed by Duncan (2002) and 
Kliatchko (2005; 2008) provides a major implementation emphasis essential for SM integration within IMC. This further exposed the need to integrate different marketing and promotional tools in the organizations' communication with stakeholders in order to avert the negative consequences of failure and to implement effective IMC in the firms' competitiveness. Above all, the current study focuses on the demand side of the business in Nigeria by administering a questionnaire to subscribers of mobile telecommunication firms who demand the firm's services.

\section{RESEARCH OBJECTIVE AND METHODOLOGY}

Since the 1990s when the concept "integration of promotional and communications tools" surfaced, it has enjoyed the interest of both academics and researchers (Seric, 2011; Cornelissen \& Lock, 2001; Caywood et al, 1991). It has, therefore, shifted the emphasis from just focusing on individuality of promotional tools such as advertising, sales promotion, direct marketing and publicity to movement towards integrated marketing communication in order to enhance customer loyalty for firms' competitiveness (Proctor \& Kitchen, 2002). In the Nigerian telecommunication industry where all the active players (mobile service providers) offer similar services to the same subscribers in a near to maturity market (Oyatoye et al. 2017), there is need for continuous assessment of effectiveness of the firms' communications tool in order to avoid waste of organisation resources that are competing for diverse need. In addition, Schultz (1992) reported that the integration problem appears to reside more with larger marketing and agency organizations than with the smaller, more flexible ones. Furthermore, he opined that marketing communications will be the major weapon in the marketing arsenal in the future of any business organisation as firms will have nothing less than integrated marketing communications programs if they are to succeed. Moreover, Oliver (1999) viewed "loyalty as a deeply held commitment to re-buy or repatronize a preferred product/service consistently in the future, thereby causing repetitive same brand purchasing, despite situational influences and marketing efforts having the potential to cause switching behaviour". The repetitiveness in purchase of company products/services is very essential to telecommunication firms as they always communicate their innovative products/services through marketing communications. How effective are these marketing communications individually or integrated in stimulating subscribers' loyalty to the firm remains a question that can be answered best by the subscribers whom the marketing communications efforts and resources are directed at. Egan (2004) emphasized that loyalty encourages an unspecified number of repeated purchases from the same supplier over a specified period. On the basis of this finding, the following research hypotheses are proposed in a null form:

\section{Ho1: integrated marketing communications dimensions do not significantly predict customer loyalty to mobile telecommunication firms in Nigeria.}

The study cross-sectional survey was designed to examine the relationship between integrated marketing communications dimensions and customer loyalty as to well as evaluate the influence of integrated marketing communications dimensions on customer loyalty to mobile telecommunication firms in Nigeria. This study is a quantitative approach aimed at collecting data in order to analyse, interpret and achieve the study objectives as well as validate or refute the hypothesis stated. The study adopted a cross-sectional survey design through the administration of a well- 
structured and validated questionnaire consisting of measures of measure of customer loyalty and the dimensions of integrated marketing communications. Mobile telecommunication subscribers in Lagos metropolis, Nigeria, Lagos was chosen for this study being one of the fastest growing cities in Africa and a commercial hub of the nation.

The target population of interest for the study includes subscribers of the four mobile telecommunications service providers (MTN, GLO, AIRTEL, ETISALAT (now known as 9MOBILE) as at the time of this study in the city. Considering the fact that the study population is not only very large but heterogeneous in nature, a multi-stage sampling method was employed to select a sample of 150 respondents who are subscribers to the network of service providers, using cluster, quota, and simple random sampling techniques.

Out of this figure administered, 134 copies were retrieved and properly filled. The questionnaire was designed based on the constructs in the study. Section A of the questionnaire concerns the socio-demographic information of the respondents while section B relates to marketing communications disciplines (direct marketing, publicity, sales promotion, advertising), consumer buying decision and customer loyalty. All the items under each of the construct were answered

on the 5-point Likert-scale, corresponding to the degree of agreement with the statement. The data collected were analysed using descriptive and inferential statistics (correlation and regression), while hypotheses were tested using the analysis of variance (ANOVA). Statistical Package for Social Scientists (SPSS IBM 20) was used in processing the data into the desired analyses in line with the study objectives and research hypotheses.

\section{RESULTS}

Table 1 revealed a summary of socio-economic characteristics of respondents that participated in the study. Regarding gender, $55.2 \%$ of the total respondents were female, while the remaining $44.8 \%$ were male. It shows that respondents in this study comprise of male and female but more female than male. On the age bracket, most of the respondents were below 20 with $33.6 \%$ of the total respondents, followed by $26.9 \%$ of the respondents who were 20 to 25 years of age. Furthermore, $20.9 \%$ of the total respondents were between the age bracket of 36 to 45 while the remaining $18.7 \%$ of the total respondents were between the ages of 26-35, thus, the study has more youths among the respondents and one-third of the total respondents were below 20 years of age. In terms of the marital status of respondents, it is seen that $94(70.1 \%)$ of the respondents were single, and the remaining $40(29.9 \%)$ were married, while none of the respondents are either divorced or widowed. In spite of this imbalance, our data were collected from both married as well as single respondents. Thus, it was revealed from this study that our respondents are all youths and customers of a mobile network service provider who can provide accurate answers related to the study. For the highest qualification of the respondents a substantial part of the respondents holds bachelor degrees across various disciplines, $90(67.2 \%)$ of the total respondents were with first-degree as academic qualification, $25(18.7 \%)$ of the respondents were with master's degree while the remaining $19(14.2 \%)$ of the respondents were with other 0 level certificates. Thus, majority (two-thirds) of the respondents were graduates of higher education (university or polytechnic), who can read and write which made them relevant in filling copies of the questionnaires for the study. 
Tab. 1 - Summary of socio-economic characteristics of the Respondents. Field survey (2017)

\begin{tabular}{|c|c|c|c|}
\hline Variables & Valid label & $\begin{array}{l}\text { Respondent } \\
(\%)\end{array}$ & Total $(\%)$ \\
\hline \multirow{2}{*}{ Gender } & Male & $60(44.8)$ & \multirow{11}{*}{$134(100)$} \\
\hline & Female & $74(55.2)$ & \\
\hline \multirow{4}{*}{ Age } & Below 20 Years & $45(33.6)$ & \\
\hline & 20- 25 years & $36(26.9)$ & \\
\hline & 26- 35 years & $25(18.7)$ & \\
\hline & $36-45$ years & & \\
\hline \multirow{2}{*}{ Marital status } & Married & $40(29.9)$ & \\
\hline & Single & $94(70.1)$ & \\
\hline \multirow{3}{*}{ Qualification } & WAEC/NECO & $19(14.2)$ & \\
\hline & B.Sc./ BA/HND & $90(67.2)$ & \\
\hline & M.Sc./MA/MBA & $25(18.7)$ & \\
\hline
\end{tabular}

Table 2 revealed the correlational matrix of the relationship between integrated marketing communications (direct marketing, publicity, sales promotion, advertising and consumer buying decision) and customer loyalty to mobile network service provider as a brand of a telecommunication network in Nigeria. This supported the position of Kliatchko, \& Schultz, (2014) that marketing communications and integration are now too important to various organisations and require more than simply looking at the tools and techniques. The strong statistically significant association between the IMC dimension and customer loyalty which naturally comes after customer satisfaction shows that it is an appropriate tool to keep the relationship between the firm and its customers mutually beneficial to both parties. It further shows that the correlation coefficient $\left(r=.232^{* *}\right)$ between consumer buying decision and customer loyalty which indicates a positive and statistically significant relationship exists between the two variables at the $99 \%$ confidence level. The relationship between customer loyalty and direct marketing is equally positive and statistically significant with a correlation coefficient $\left(\mathrm{r}=.375^{* *}\right)$. The relationships between customer loyalty and three other components of integrated marketing communications (publicity, sales promotion and advertising) were also positively strong and statistically significant with correlation coefficients $\left(\mathrm{r}=.514^{* *} ; \mathrm{r}=.470^{* *}\right.$; and $\left.\mathrm{r}=.562^{* *}\right)$ respectively. Concerning relationships that exist between consumer buying behaviour and other integrated marketing communications variables (direct marketing, publicity, sales promotion and advertising), the results reveal mixed relationships among the variables, while there are positive relationships between consumer buying decision, direct marketing and publicity while there are inverse relationships between consumer buying behaviour, sales promotion and advertising. Thus, consumer buying decision is negatively correlated with advertising and sales promotion, which means that an isolating component of integrated marketing communications at influencing consumer choice of network service providers in Nigeria may not yield the desired outcome as such promotional efforts may be likened to what Kotler and Keller (2006) describes as pouring water into a basket or 
bucket that is leaking, which must be avoided in the highly competitive and fast-growing Nigeria's telecommunication industry. More so, the relationships between publicity, sales promotion and advertising were equally positive and significant with correlation coefficients $\left(\mathrm{r}=.358^{* *} ; \mathrm{r}\right.$ $=.288^{* *}$; and $\mathrm{r}=.614^{* *}$ ) respectively with the $99 \%$ confidence level. In all, the results revealed positive and significant relationships among all the variables.

Tab. 2 - Correlational matrix on integrated marketing communication and customer loyalty. Source: authors

\begin{tabular}{|l|l|l|l|l|l|l|}
\hline Variables & 1 & 2 & 3 & 4 & 5 & 6 \\
\hline Customer Loyalty & 1 & & & & & \\
\hline Consumer Buying Decision & $.232^{* *}$ & 1 & & & & \\
\hline Direct Marketing & $.375^{* *}$ & $.204^{* *}$ & 1 & & & \\
\hline Publicity & $.514^{* *}$ & $.352^{* *}$ & $.697^{* *}$ & 1 & & \\
\hline Sales Promotion & $.470^{* *}$ & -.015 & $.345^{* *}$ & $.358^{* *}$ & 1 & \\
\hline Advertising & $.562^{* *}$ & -.104 & .192 & $.288^{* *}$ & $.614^{* *}$ & 1 \\
\hline
\end{tabular}

**. Correlation is significant at the 0.01

To explore the relationships among the variables independently and jointly, the regression analysis is imperative as it helps to analyse the effect of independent variables (integrated marketing communications) on the dependent variable (customer loyalty) (McMillan \& Schumacher, 2001).

Thus, Table 3 shows a multiple regression analysis that explains the amount of variance in customer loyalty accounted for by each element of integrated marketing communications (direct marketing, publicity, sales promotion, and advertising). The result reveals the R-value of 0.695, which suggests a very strong positive and significant relationship between integrated marketing communications and customer loyalty in Nigeria. The $\mathrm{R}^{2}$ value is close to average, meaning that integrated marketing communications contribute $48.3 \%$ to customer loyalty to a mobile network service provider in Nigeria. In fact, we can generalize the model, as there is a significant positive relationship between the variables, as represented by close to $1 / 2$ of $100 \%$ been the variation accounted for by the integrated marketing communications as shown by the value of the adjusted $\mathrm{R}^{2}$. Also, it is worthy to note that the Durbin Watson statistic is in the vicinity of 2 , indicating the absence of autocorrelation which could have affected our model by inflating R2 and making the model looks better than it was.

The ANOVA in Table 3 also reveals that the overall regression model can act as a good predictor of the outcome variable, thus, with F statistic value of 23.906 significant at 1\%, the model is fit. Thus, the ANOVA shows the amount of variation in the regression model. The value of Fstat is 23.906, which is the ratio of the overall fit of a regression model. With a high F - test signals that a model possesses significant explanatory power, which must be compared with a critical value to determine its importance. The model is significant at $0.000(\mathrm{p}<0.01)$, which means $1 \%$ significant level and $99 \%$ confidence level. Since F calculated is 23.906 and F tabulated is 3.782 , that is Fcal is greater than Ftab, the null hypothesis that says there is no significant relationship 
between integrated marketing communications and customer loyalty is not supported thereby leading to study supporting the alternative hypothesis. Therefore, there exists a significant positive relationship between integrated marketing communications and customer loyalty to mobile network service provider in Nigeria which is (significant) at $1 \%$ level of significance.

Table 3 also shows the ' $\beta$ ' and t-ratio coefficients of each of the five predictors' variables on the dependent variable. It was observed that all the five independent variables (direct marketing, publicity, sales promotion, advertising and consumer buying decision) have predictive capacity on customer loyalty; however, only three of the variables (publicity, consumer buying behaviour and advertising) are significant at $1 \%$. For publicity, the $(\beta=0.265$, t-ratio $=2.732 ; \mathrm{p}<0.007)$ respectively, it revealed that a level increase in publicity effort of the organisation will improve customer loyalty of the firm by $26.5 \%$. Thus, persuasive and public awareness must be continuous by mobile network service providers in order to highlight the firm's capability at all time in meeting customer needs through various research-driven and innovative products/services, in order to ensure sustainable customer loyalty to the firm in the mix competition within the industry. Contrary to the position of Csikósová et al., (2014) and Jones (2008) that none of the four elements of IMC (direct marketing, advertising, sales promotion and public relation) is inherently superior or inferior; they all have important functions in an integrated campaign. It is evident that subscribers in the telecommunication industry favoured public relation and advertisement more as promotional tools that influence their loyalty to a telecoms service provider. This may suggest that promotional tools may carry different weights across sectors of the economy. This weight is very essential in managing the promotional budget of the organisation effectively.

In addition, the ' $\beta$ ' and t-ratio coefficients (' $\beta$ ' $=.439$, t-ratio $=5.311 \mathrm{p}<0.01)$ respectively shows that a level increase in advertising campaign will increase customer loyalty to the firm by $43.9 \%$. This suggests that a refinement of advertising strategies of the firm towards more informative, persuasion and reminding subscribers of service provider's ability to meet their mobile communication need through quality voice and data deals will spur better customer loyalty to the service provider that guaranteed this.

The $\beta$-value of consumer buying decision (.178) is significant at 0.000 which shows that consumer buying decision of subscribers has a significant positive contribution to the achievement and delivery of business goals through customer loyalty.

Based on the findings from this study, respondents were of the view that integrated marketing communications efforts of a firm are crucial to accomplishing sustainable customer loyalty, which is ultimately required for attaining the organisational goal. Moreover, with the negative correlation between consumer buying decision, advertising and sales promotion, it shows that it is not good for a firm to single-out one component of integrated marketing communications as explored in the literature review done by Thaichon and Quach (2015). Moreover, marketing strategy directed against effectiveness of IMC programs as perceived by subscribers may not yield the expected outcome for the firm, rather promotional mix should be integrated to facilitate customer loyalty both in the short and long run.

Priority should be given to publicity, advertising and any other promotional factor that can influence consumer buying decision in the firms' promotional budget as the study revealed that 
integrated marketing communications elements have the capacity to improve customer loyalty to a service provider collectively than implementing each in isolation. This corroborates the view of Kotler and Armstrong (2008) that the ability of any firm to effectively position its brands favourably in the market and ultimate succeess lies significantly on the firms' right investment in marketing communications. Thus, managers should plan and recognize the strategic role of integrated marketing communications at adding value to firms' service delivery efforts.

The result also supported the view of Luxton et al., (2015) who opined that IMC have capability to drive a brand's financial performance through influencing the effectiveness of communication campaigns and the brand's market-based performance. The current study result indicates a substantial contribution of IMC dimension in driving customer loyalty to telecommunication firms in Nigeria, thereby capitalizing on the repeated purchase and patronage for effective business performance since no telecommunication firm can survive without profitable subscribers.

Furthermore, this study corroborates the study of Khizar et al (2016), who found a positive significant correlation and effect of IMC on customer loyalty. Although, the study reported the variables from supplier side (managers) in the brewery sector of Pakistan while this study focuses on the demand (customer) side in the Nigeria telecommunication sector. Thus, this suggests that from both the supply and demand side of business and two different sectors, IMC influence customer loyalty significantly. Assessing IMC from demand side seems better because it gives companies an opportunity to get feedback on budgetary allocation to promotional tools since customers` responses reflect their needs, wants, desires, and behaviour to firm activities.

Tab. 3 - Regression results on integrated marketing communication and customer loyalty.

Source: authors

\begin{tabular}{|c|c|c|c|c|c|c|}
\hline \multicolumn{7}{|c|}{ Model Summary } \\
\hline Model & $\mathrm{R}$ & R Square & $\begin{array}{l}\text { Adjusted R } \\
\text { Square }\end{array}$ & \multicolumn{3}{|c|}{ Std. Error of the Estimate } \\
\hline 1 & $.695 a$ & .483 & .463 & \multicolumn{3}{|l|}{3.224} \\
\hline \multicolumn{7}{|c|}{$\begin{array}{l}\text { a) Predictors: (Constant), Consumer buying behaviour, sales promotion, direct marketing } \\
\text { advertising, publicity. } \\
\text { b) Customer Loyalty. }\end{array}$} \\
\hline \multicolumn{7}{|c|}{ ANOVA } \\
\hline Model & Sum of Squares & Df & $\begin{array}{l}\text { Mean } \\
\text { Square }\end{array}$ & $\mathrm{F}$ & Sig. & \\
\hline \multirow[t]{3}{*}{1} & Regression & 1242.515 & 5 & 248.503 & 23.906 & $.000 \mathrm{~b}$ \\
\hline & Residual & 1330.537 & 128 & 10.395 & & \\
\hline & Total & 2573.052 & 133 & & & \\
\hline \multicolumn{7}{|c|}{ a) Dependent Variable: Customer Loyalty. } \\
\hline \multicolumn{7}{|c|}{$\begin{array}{l}\text { b) Predictors: (Constant), Consumer buying behaviour, sales promotion, direct marketing } \\
\text { advertising, publicity. }\end{array}$} \\
\hline
\end{tabular}




\begin{tabular}{|c|c|c|c|c|c|c|}
\hline \multicolumn{7}{|c|}{ Coefficients } \\
\hline \multirow{2}{*}{\multicolumn{2}{|c|}{ Model }} & \multicolumn{2}{|c|}{$\begin{array}{l}\text { Non-standardized Coef- } \\
\text { ficients }\end{array}$} & \multirow{2}{*}{$\begin{array}{l}\text { Standard- } \\
\text { ized Coef- } \\
\text { ficients } \\
\text { Beta }\end{array}$} & \multirow[t]{2}{*}{$\mathrm{T}$} & \multirow[t]{2}{*}{ Sig. } \\
\hline & & $\mathrm{B}$ & Std. Error & & & \\
\hline \multirow{6}{*}{1} & (Constant) & -3.527 & 2.959 & & -1.192 & .235 \\
\hline & Direct Marketing & .050 & .122 & .037 & 0.407 & 0.685 \\
\hline & Publicity & .376 & .138 & .265 & 2.732 & $0.007^{*}$ \\
\hline & Sales Promotion & .122 & .108 & .095 & 1.130 & 0.261 \\
\hline & Advertising & .483 & .091 & .439 & 5.311 & $0.000^{*}$ \\
\hline & $\begin{array}{l}\text { Consumer Buy- } \\
\text { ing Decision }\end{array}$ & .316 & .124 & .178 & 2.550 & $0.012 *$ \\
\hline
\end{tabular}

a) Dependent Variable: Customer Loyalty.

${ }^{*} \beta$ is significant at the 0.01 and 0.05 levels.

\section{CONCLUSION}

This study provides for academics, managers in the service industry and other stakeholders the insight into the relevance of integrated marketing communications on customer loyalty thereby contributing to better understanding of customer loyalty stimulus in the fastest growing telecommunication industry in Africa. From the findings of this study, the paper concludes that integrated marketing communications are viable strategies to strengthen customer loyalty to the telecommunication service providers in Nigeria. It further suggests an important implication for marketing managers in the industry to prioritize their strategies on the basis of IMC dimension that makes the greatest contribution to the criterion of interest, with a higher beta coefficient in their budgetary allocation for the optimal promotional mix, thus, achieving the organisational goal both in short and long-run (customer retention and repeated patronage in the mix of competition in the industry).

Furthermore, this study revealed significant positive relationships between the IMC dimensions, customer buying decision and customer loyalty. This indicates that the variables are strongly associated, suggesting a good connection between an organisation activities (IMC dimension such as advertising, publicity, sales promotion, direct marketing) and consumer responses through their decision as subscribers towards patronizing a particular network service provider in Nigeria. Thus, IMC is an essential ingredient for firms to communicate through integration of various promotional means in order to succeed in the market and outperform their competitors providing similar telecommunication services (voice, text and internet). Telecommunications firms should invest appropriately on the IMC dimensions with high beta values, as they indicate positive predictive ability to enhance customer loyalty to the firm, thereby helping telecoms firms in actualizing both short and long-term benefits of marketing communications.

As subscribers' demands for mobile telecommunication products and services in a near to matured market like Nigeria, where the total number of subscribers is approaching $80 \%$ of the total 
population (143 million out of the estimated 180 million) as in August 2017, requires competing telecom firms to ensure holistic promotional mix like IMC in order to continually attract new subscribers on the firms' portfolio as well as attain higher customer loyalty which can strengthen business survival. In a highly competitive business environment that telecommunication firms in Nigeria operate, there is need for effective integrated marketing communications that influences the purchase behaviour of stakeholders positively to the company.

The paper further supports the importance of IMC activities in the telecommunication industry been a major influence of subscribers' loyalty to a mobile network service provider. This is evident in conclusion based on the $48.3 \%$ variation in customer loyalty accounted for by IMC implementation in a firm, thus, IMC is a strategic tool for targeting subscribers to patronize and retain them with a mobile telecom service provider for a long time.

Telecommunication firms in Nigeria are advised based on the result of the study to build distinctive capability in establishing effective IMC programs for their organisation in order to benefit from the direct and indirect influences of IMC on customer loyalty to the firm's product and services as well overall performance of the firm in justifying corporate existence.

\section{Limitations of the study}

This study tested the relationship and causal links between integrated marketing communications dimension and loyalty to Nigeria telecommunication service providers. Generalising the result of this study may be limited to the service industry, since the result may not be applicable in other sub-sector of the economy such as the manufacturing industry where the flexibility of churn and customer switching is not as pervasive. Also, the direction of causality may change from one sector of the economy to another. In addition, the sample consisted of subscribers of the four active mobile-telecommunication firms at the time of data collection for this study. It is noteworthy that as soon as the number of an active player (GSM service provider) increases with modern means of marketing communications, the coefficient of variation of each of the IMC dimension may be altered. Also, the assortment of promotional tools varies across sectors of the economy. The present study focused on the subscribers' perception of integrated marketing communications influence on their loyalty to a telecommunication service provider current offerings; other central concepts of relationship theory, such as trust and satisfaction, were not isolated. Generally, we suggest that the result of this study should be interpreted with caution on the basis of these realities. In line with the theoretical frame work for this study, no intervening variables were considered. We suggest that future studies should investigate the mediatory roles of other extraneous factors between stimulus -organism (IMC and consumers) and between consumer-responses such as patronage, satisfaction and loyalty.

\section{References}

1. Anderson, E, W. \& Mansi, S. A. (2009). Does customer satisfaction matter to investors? Findings from the bond market. Journal of Marketing Research, 46 (2), 703-714. https://doi. org/10.1509/jmkr.46.5.703

2. Anderson, E. W. \& Mittal, V. (2000). Strengthening the satisfaction-profit chain. Journal of Service Research, 3 (2), 107-120. https://doi.org/10.1177/109467050032001 
3. Anderson, H. \& Jacobsen, P. N. (2000) Creating loyalty: Its strategic importance in your customer strategy. In S. A. Brown (ed.), Customer relationship management. Ontario: John Wiley.

4. Athanasopoulou, P. (2009). Relationship quality: a critical literature review and research agenda. European Journal of Marketing, 43 (5/6), 583-610, https://doi.org/10.1108/03090560 910946945

5. Aurier, P., \& N'Goala, G. (2010). The differing and mediating roles of trust and relationship commitment in service relationship maintenance and development. Journal of the Academy of Marketing Science, 38(3), 303-325. https://doi.org/10.1007/s11747-009-0163-z

6. Barsky, J. (1994). World-class satisfaction. Irwin Professional Publishing, Burr Ridge, IL.

7. Chaihanchanchai, P., \& Anantachart, S. (2017). Through the looking glass: Understanding Thai academics' viewpoints on integrated marketing communications. Kasetsart Journal of Social Sciences, xxx-in press, 1-9. https://doi.org/10.1016/j.kjss.2017.10.003

8. Caywood, C., Schultz, D. \& Wang, P. (1991). Integrated Marketing Communications: A Suvey of National Good Advertisers. Unpublished report, Medill School of Journalism, Northwestern University, June 1991.

9. Cogoljević, M., Dimitrijević, L. \& Cogoljević, V. (2017). Research on the influence integrated marketing communications at enterprises business in the Republic of Serbia. Euro Economica, 36(2), 21-33.

10. Cornelissen, J. P. \& Lock, A. R. (2001). The appeal of integration: Managing communications in modern organizations. Marketing Intelligence \& Planning, 19 (6), 425-431. http://doi. org/10.1108/EUM0000000006110

11. Csikósová, A., Antošová, M. \& Čulková, K., (2014). Strategy in direct and interactive marketing and integrated marketing communications. Procedia-Social and Behavioral Sciences, 116(2014), 1615-1619. http://doi.org/10.1016/j.sbspro.2014.01.444

12. Duncan, T. R. (2002). IMC: Using advertising and promotion to build brands. New York: McGrawHill Companies.

13. Duncan, T. \& Moriarty, S. (1998). A communication-based marketing model for managing relationships. Journal of Marketing, 62 (April), 1-13. http://doi.org/10.2307/1252157

14. Drucker, P. F. (1973). Management: Tasks, Responsibilities, Practices. Harper and Row, New York.

15. Edvardsson, B., Johnson, M. D., Gustafsson, A., \& Strandvik, T. (2000). The effects of satisfaction and loyalty on profits and growth: Products versus services. Retrieved [15th April 2018], from Cornell University, School of Hospitality Administration site: http://scholarship.sha.cornell.edu/ articles/714

16. Egan, J. (2004). Relationship Marketing: Exploring Relational Strategies in Marketing. Pearson Education, Harlow.

17. Fornell, C., S. Mithas, F. V. \& Morgeson, III. (2009). The economic and statistical significance of stock returns on customer satisfaction. Marketing Science, 28 (5), 820-825. https://doi. org $/ 10.1287 / \mathrm{mksc} .1090 .0505$

18. Hallowell, R. (1996). The relationships of customer satisfaction, customer loyalty, and 
profitability: an empirical study. International Journal of Service Industry Management, 7(4), 27-42, https://doi.org/10.1108/09564239610129931

19. Hänninen, N., \& Karjaluoto, H. (2017). The effect of marketing communication on business relationship loyalty. Marketing Intelligence and Planning, 35 (4), 458-472. https://doi.org/10.1108/ MIP-01-2016-0006

20. Harris, L. C. \& Goode, M. M. H. (2004). The four levels of loyalty and the pivotal role of trust: A study of online service dynamics. Journal of Retailing, 80(2), 139-158. https://doi. org/10.1016/j.jretai.2004.04.002

21. Hegner-Kakar, A. K., Richter, N. F. \& Ringle, C. M. (2018). The customer loyalty cascade and its impact on profitability in financial services. In N.K. Avkiran, C.M. Ringle. (2018). (eds.), Partial Least Squares Structural Equation Modeling, International Series in Operations Research \& Management Science Springer International Publishing A G, 267, 53-75, https://doi.org/10.1007/9783-319-71691-6_3

22. Hubber, F., Herrmann, A. \& Morgan, R.E. (2001). Gaining competitive advantage through customer value oriented management. Journal of Consumer Marketing, 18 (1), 41-53. https://doi. $\operatorname{org} / 10.1108 / 07363760110365796$

23. Jones, S. K. (2008). Creative strategy in direct and interactive marketing. Fourth Edition. Maximum Press.

24. Khizar, N., Farooqi, S., Rehmat, M. \& Naz, F, (2016). Effect of integrated marketing communication components on brand awareness and customer loyalty in beverage sector. Paradigms: A Research Journal of Commerce Economics, and Social Sciences, 10 (2), 64-73.

25. Kliatchko, J., \& Schultz, D. E. (2014). Twenty years of IMC: A study of CEO and CMO perspectives in the Asia-Pacific region. International Journal of Advertising, 33(2), 373-390, https://doi.org/10.2501/IJA-33-2-373-390

26. Kliatchko, J. G. (2008). Revisiting the IMC construct. International Journal of Advertising, 27 (1), 133-160, https://doi.org/10.1080/02650487.2008.11073043

27. Kliatchko, J. G. (2005). Towards a new definition of integrated marketing communications (IMC). International Journal of Advertising, 24 (1), 7-34, https://doi.org/10.1080/02650487.200 5.11072902

28. Kotler, P. (2003). Marketing Management: Analysis, Planning, Implementation and Control, (11th ed.). New York: Prentice-Hall.

29. Kotler, P. \& Armstrong, G. (2008). Principles of marketing, (12th ed.). Pearson Education, New Jersey.

30. Kotler, P., Armstrong, G., Saunders, J., \& Wong, V. (1999). Principles of Marketing, 2nd Ed.). Europe: Prentice-Hall.

31. Kotler, P \& L. Keller, (2006). Marketing management. 12th ed. New Jersey: Pearson Prentice Hall.

32. Larivière, B. (2008). Linking perceptual and behavioral customer metrics to multi-period customer profitability - a comprehensive service-profit chain application. Journal of Service Research, 11 (1), 3-21, https://doi.org/10.1177/1094670508319092 
33. Leong, L. Y., Jaafar, N. I. \& Sulaiman, A. (2017). Understanding impulse purchase in Facebook commerce: does Big Five matter? Internet Research, 27 (4), 786-818, https://doi. org/10.1108/IntR-04-2016-0107

34. Li, E.Y., Liao, C.H. \& Yen, H. J. R. (2013). Co-authorship networks and research impact: A social capital perspective. Research Policy, 42 (9), 1515-1530, http://dx.doi.org/10.1016/ j.respol.2013.06.012

35. Luxton, S., Reid, M., \& Mavondo, F. (2015). Integrated marketing communication capability and brand performance. Journal of Advertising, 44 (1), 37-46, https://doi.org/10.1080/009133 67.2014 .93493

36. McMillan, J. H., \& Schumacher, S. (2001). Research in education. A conceptual Introduction (5th ed.). New York: Longman.

37. Mehrabian, A. \& Russell, A. (1974). An Approach to Environmental Psychology. MIT Press, Cambridge, Mass.

38. Oliver, R. L. (1999). Whence customer loyalty? Journal of Marketing, 63 (1), 33-44. https://doi. $\operatorname{org} / 10.2307 / 1252099$

39. Oyatoye E. O., Adebiyi, S. O. \& Amole, B. B. (2017). Analytical hierarchy process for estimating Subscribers perception of brand equity dimensions on purchase decision of Nigerian mobile telecommunication services. Yugoslav Journal of Operations Research, 27 (4), 391 412, https://doi.org/10.2298/YJOR171104022O

40. Oyatoye, E. O., Adebiyi S. O. \& Amole, B. B. (2015). Modeling switching behaviour of Nigeria global system for mobile communication multiple SIMs subscribers` using Markov chain analysis. Journal of Operations Management, 14 (1), 7-31.

41. Olimpia, O. \& Mihaela, E. (2015). The influence of the integrated marketing communication on the consumer buying behaviour. Procedia Economics and Finance, 23 (1), 1446-1450, https:// doi.org/10.1016/S2212-5671(15)00446-3

42. Proctor, T., \& Kitchen, P. (2002). Communication in post-modern integrated marketing. Corporate communications: An International Journal, 7 (3), 144-154. https://doi.org/10.1108/135 63280210436754

43. Serić, M. \& Gil-Saura, I. (2011). Integrated marketing communications and information and communication technology in the hotel sector: An analysis of their use and development in Dalmatian first-class and luxury hotels. Journal of Retail \& Leisure Property, 9(5), 401-414, https://doi.org/10.1057/rlp.2011.4

44. Schultz, D. E. (1992). Integrated marketing communications. Journal of Promotion Management, 1 (1), 99-104, https://doi.org/10.1300/J057v01n01_07

45. Schultz, D. E. (1993). Four basic rules lay groundwork for integration. Marketing News, 27(1), 725.

46. Shimp, T. A., \& Andrews, J. C. (2013). Advertising, promotion, and other aspects of integrated marketing communications (9th ed.). Mason, $\mathrm{OH}$ : Cengage.

47. Thaichon, P. \& Quach, T. N. (2015). Integrated marketing communications and their influences on brand loyalty: a Thai perspective. International Journal of Studies in Thai Business, Society \& Culture, 2 (1), 55-79. 
48. Tichindelean, M. (2015). The influence of marketing communication on the consumer's buyer behaviour - a Relationship marketing approach. Studies in Business and Economics, 10 (1), 140-145. https://doi.org/10.1515/sbe-2015-0013

49. Van Vuuren, T., Roberts Lombard, M. \& Van Tonder, E. (2012). Customer satisfaction, trust and commitment as predictors of customer loyalty within an optometric practice environment. Southern African Business Review, 16 (3), 81-93.

50. Wang, Chung-Yu \& Wu, Li-Wei. (2012). Customer loyalty and the role of relationship length. Managing Service Quality-An International Journal, 22 (1), 58-74, https://doi.org/10.1108/09604 521211198119

51. Wu, Y. \&. Li, E. T. (2016). Marketing mix, customer value, and customer loyalty in social commerce: A stimulus-organism-response perspective. Internet Research. https://doi. org/10.1108/IntR-08-2016-0250

\section{Contact information}

Olaolu Joseph Oluwafemi Ph. D.

Business Administration Department,

Faculty of Management Sciences,

University of Lagos,

Akoka, Lagos. Nigeria.

E-mail:ooluwafemi@unilag.edu.ng

Sulaimon Olanrewaju Adebiyi Ph. D.

Business Administration Department,

Faculty of Management Sciences,

University of Lagos,

Akoka, Lagos. Nigeria.

E-mail:soadebiyi@unilag.edu.ng 